\section{BEYOND 2020, VISION OF THE FUTURE: SELECTED PAPERS FROM THE SIXTH DECENNIAL NATIONAL IRRIGATION SYMPOSIUM}

\author{
Freddie R. Lamm ${ }^{1, *}$, Michael D. Dukes ${ }^{2,3}$, Kenneth C. Stone ${ }^{4}$, Brent Q. Mecham ${ }^{5}$ \\ ${ }^{1}$ Northwest Research-Extension Center, Kansas State University, Colby, Kansas, USA. \\ 2 Department of Agricultural and Biological Engineering, University of Florida, Gainesville, Florida, USA. \\ ${ }^{3}$ Center for Land Use Efficiency, University of Florida, Gainesville, Florida, USA. \\ ${ }^{4}$ USDA-ARS Coastal Plain Soil, Water, and Plant Conservation Research Unit, Florence, South Carolina, USA. \\ 5 The Irrigation Association, Fairfax, Virginia, USA. \\ * Correspondence: flamm@ksu.edu.
}

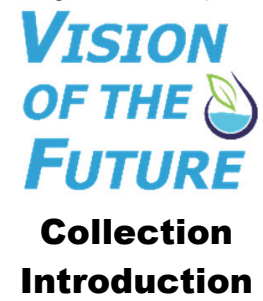

\title{
HighLIGHTS
}

- ASABE/IA 6th National Irrigation Symposium includes 80 papers, with 36 introduced here in this Special Collection.

- Papers include current irrigation research about ET, management, turf systems, technology, humid region, water supply.

- Irrigation in the U.S. is growing more rapidly in humid regions, and pressurized irrigation continues to grow in usage.

- There has been much progress in irrigation science in the last decade, and the vision of the future looks bright.

\begin{abstract}
This article introduces the ASABE Special Collection associated with the 6th Decennial National Irrigation Symposium: Beyond 2020, Vision of the Future. This U.S. symposium, jointly sponsored by ASABE and the Irrigation Association in December 2021, was postponed from 2020 due to the pandemic and consists of approximately 80 presentations, of which 36 were accepted as journal articles for this Special Collection. Irrigated land area appears to be growing slightly in the U.S. but is shifting geographically somewhat toward humid regions. Pressurized irrigation continues to grow, and gravity-fed irrigation continues to decline. Competition for stressed water resources among diverse water users remains great, and smaller numbers of irrigation scientists are available to meet the informational needs. Improved ability to acquire, assess, and use water and crop information helps to meet these challenges. This article discusses irrigation research progress in evapotranspiration (ET), irrigation management, turf systems, sensors and technologies, irrigation strategies in the humid region, and water supply. Challenges and opportunities continue to exist for irrigation in the U.S., but progress in the last decade has been steady, and a good vision for the future of irrigation beyond 2020 is anticipated.
\end{abstract}

Keywords. Evapotranspiration, Irrigation, Irrigation management, Irrigation scheduling, Irrigation systems, Turf and landscape irrigation.

I $\mathrm{n}$ March of 2019, the program committee of the 6th Decennial National Irrigation Symposium (NIS) established the symposium titled Beyond 2020, Vision of the Future. The intended wordplay was that it is possible to have vision better than $20 / 20$, and it was hoped that the symposium would provide such a vision of the future for irrigation in the U.S. Little did the program committee know that, within a year, the symposium title would take on new meaning, with the COVID-19 pandemic necessitating postponement of the 6th Decennial NIS.

ASABE (formerly ASAE) has sponsored the NIS every ten years since 1970; beginning in 1990, the Irrigation

Submitted for review on 10 March 2021 as manuscript number NRES 14574; approved for publication as a Research Brief and as part of the National Irrigation Symposium 2020 Collection by the Natural Resources \& Environmental Systems Community of ASABE on 2 June 2021.

Mention of company or trade names is for description only and does not imply endorsement by the USDA. The USDA is an equal opportunity provider and employer.
Association (IA) became a co-sponsor. These decennial events provide a forum to discuss the status and recent progress of research, extension, state and federal agency, and industry efforts to advance the effectiveness of irrigation practices and technologies, as well as to project a path forward amid the successes and challenges. Additional discussion of some of the earlier Decennial NIS is provided by Dukes et al. (2012).

At the time of this writing, it is anticipated that 80 papers will be presented at the 6th Decennial NIS, which is currently scheduled for December 2021 in San Diego, California. The authors of these papers had the option of seeking simultaneous dual publication in the symposium proceedings and through the journal peer-review process. A total of 36 papers were published in both media, and these peer-reviewed journal articles are contributions to the largest ASABE Special Collection prepared thus far. These journal articles are summarized in the following sections along with some additional contextual discussion of the present status of irrigation in the U.S. and a vision of the future beyond 
2020. This collection builds on two recent ASABE Special Collections with contributions from the 5th Decennial NIS in 2010 (Dukes et al., 2012) and the Emerging Technologies for Sustainable Irrigation symposium in 2015 (Lamm et al., 2016), both jointly sponsored by ASABE and IA.

\section{STATUS OF IRRIGATION IN THE U.S.}

Overall, it appears that irrigated land area $(\sim 23.5 \mathrm{Mha})$ has continued to increase slightly in the U.S. (fig. 1), although we note some discrepancies in the various 2018 USDA-NASS Farm and Ranch Irrigation Survey tables used to prepare this summary. The concentration of irrigated land area has migrated somewhat within the U.S., with the top ten states losing approximately $2 \%$ of their area in the last decade, while the bottom 40 states have increased their irrigated land area by approximately $13 \%$. Although irrigation is most heavily concentrated in the semi-arid and arid western U.S., two Mid-South states, Arkansas and Mississippi, have the third and ninth largest irrigated land areas, respectively (USDA-NASS, 2018).

The geographic shift toward more humid regions is likely to continue with increasing competition for water resources in the western U.S. and an increasing need to mitigate crop production risks in the eastern semi-humid and humid regions. These geographic changes in irrigation within the U.S. require some adjustment to the future of irrigation, perhaps relying more on optimization schemes rather than on schemes for crop yield maximization or for immaculate turf landscapes. New and emerging irrigation technologies will continue to be needed in the water-stressed western areas, as well as in the eastern areas of the U.S. where irrigation is increasing.

The adoption of pressurized irrigation systems (i.e., sprinkler and microirrigation) continues in the U.S. (fig. 2), with surface gravity systems continuing to decrease. The percentage of pressurized systems increased from $37 \%$ to $65 \%$ during the period 1978 through 2017. In the last decade, the sprinkler irrigated area seems to have plateaued for now ( $\sim 3 \%$ increase), the microirrigated area is still rapidly increasing ( $\sim 56 \%$ increase $)$, and the surface gravity irrigated

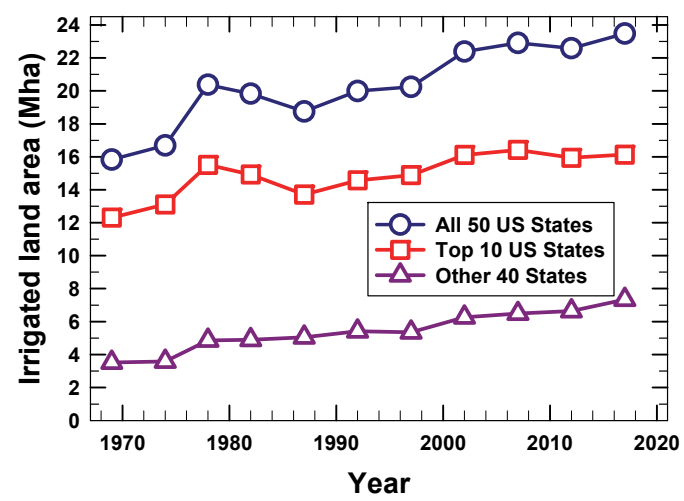

Figure 1. Irrigated land area in the U.S., the top ten irrigated states, and the remaining 40 states during the period 1969 through 2017. Data from USDA-NASS Farm and Ranch Irrigation Surveys (USDA-NASS, 1994, 2004, 2010, 2014, 2018). Note that there are some unreconcilable differences in irrigated land area between figures 1 and 2 when considering a total land area. area has continued its steady decline ( $\sim 8 \%$ decrease). The decline in surface gravity systems may be moderated in the future, considering that $35 \%$ of the total surface gravity land area is in the Mid-South states of Arkansas, Mississippi, Louisiana, and Missouri. In this region, $71 \%$ of surface gravity systems use single-year poly-pipe for water distribution, and these less-expensive systems are often more economical than pressurized systems.

\section{DISCUSSION OF 6TH DECENNIAL NIS JOURNAL ARTICLES}

The 36 journal articles comprising this ASABE Special Collection can be loosely categorized into the following topics (table 1):

- Evapotranspiration (improved estimation procedures and on-farm usage).

- Irrigation management (modeling, scheduling, and strategies).

- Irrigation systems (sprinkler, surface gravity, and microirrigation).

- Turf and landscape irrigation.

- Technology and innovation (sensors, technology usage and adoption, extension/education)

- Irrigation in the humid region.

- Water supply.

\section{EVAPOTRANSPIRATION (IMPROVED ESTIMATION Procedures AND ON-FARM Usage)}

Evapotranspiration (ET) is a key factor and metric in both evaluation of irrigation strategies and management of crops, turf, and landscapes. Seven journal articles for this ASABE Special Collection were related to either improving ET estimation procedures or improving the on-farm usage of ET data.

Standardized procedures to estimate ET for short and tall reference crops (Allen et al., 1998, 2005; Walter et al., 2000) are well established. However, for estimation of actual crop ET, the reference ET needs to be modified by coefficients (e.g., crop, landscape, stress, cultural, or environmental

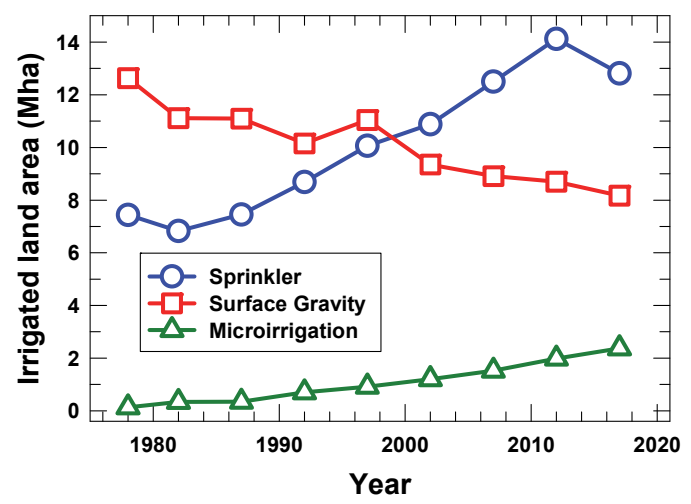

Figure 2. Irrigated land area in the U.S. by sprinkler, surface gravity, and microirrigation methods during the period 1978 through 2017. Data from USDC or USDA Farm and Ranch Irrigation Surveys (USDC, 1979, 1990; USDA-NASS, 1994, 2004, 2010, 2014, 2018). Note that there are some unreconcilable differences in irrigated land area between figures 1 and 2 when considering a total land area. 
Table 1. Summary of articles included in the 2021 ASABE Special Collection "Beyond 2020, Vision of the Future: Selected Papers from the 6th Decennial National Irrigation Symposium".

\begin{tabular}{|c|c|c|c|}
\hline Authors & Title & Key Topics & DOI \\
\hline $\begin{array}{l}\text { Allen, R. G., Dukes, M. D., } \\
\text { Snyder, R. L., Kjelgren, R., } \\
\text { \& Kilic, A. }\end{array}$ & $\begin{array}{l}\text { A review of landscape water requirements using } \\
\text { a multi-component landscape coefficient. }\end{array}$ & $\begin{array}{c}\text { ET; } \\
\text { turf/landscape }\end{array}$ & https://doi.org/10.13031/trans.13948 \\
\hline $\begin{array}{l}\text { Allen, R. G., Robison, C. W., } \\
\text { Huntington, J., Wright, J. L., } \\
\text { \& Kilic, A. }\end{array}$ & $\begin{array}{l}\text { Applying the FAO-56 dual } K_{C} \text { method for } \\
\text { irrigation water requirements over large } \\
\text { areas of the western U.S. }\end{array}$ & ET & https://doi.org/10.13031/trans.13933 \\
\hline $\begin{array}{l}\text { Andales, A. A., Bartlett, A. C., } \\
\text { Bauder, T. A., \& Wardle, E. M. }\end{array}$ & $\begin{array}{l}\text { Adapting a cloud-based irrigation scheduler } \\
\text { for sugar beets in the High Plains. }\end{array}$ & $\begin{array}{l}\text { ET; } \\
\text { irrig. mgmt. }\end{array}$ & https://doi.org/10.13031/aea.13902 \\
\hline $\begin{array}{l}\text { Andrade, M. A., O’Shaughnessy, S. A., } \\
\text { \& Evett, S. R. }\end{array}$ & $\begin{array}{l}\text { ARSPivot, a sensor-based decision support } \\
\text { software for variable-rate irrigation center } \\
\text { pivot systems: Part A. Development. }\end{array}$ & $\begin{array}{l}\text { Irrig. systems; } \\
\text { tech. and } \\
\text { innovation }\end{array}$ & https://doi.org/10.13031/trans.13907 \\
\hline $\begin{array}{c}\text { Andrade, M. A., O’Shaughnessy, S. A., } \\
\text { \& Evett, S. R. }\end{array}$ & $\begin{array}{c}\text { ARSPivot, a sensor-based decision support } \\
\text { software for variable-rate irrigation center } \\
\text { pivot systems: Part B. Application. }\end{array}$ & $\begin{array}{l}\text { Irrig. systems; } \\
\text { tech. and } \\
\text { innovation }\end{array}$ & https://doi.org/10.13031/trans.13908 \\
\hline $\begin{array}{l}\text { Barnes, E. M., Campbell, B. T., } \\
\text { Vellidis, G., Porter, W., Payero, J., } \\
\text { Leib, B., ... \& Thorp, K. }\end{array}$ & $\begin{array}{c}\text { Forty years of increasing cotton's water } \\
\text { productivity and why the trend } \\
\text { will continue. }\end{array}$ & $\begin{array}{l}\text { Tech. and } \\
\text { innovation }\end{array}$ & https://doi.org/10.13031/aea.13911 \\
\hline $\begin{array}{l}\text { Baumhardt, R. L., Haag, L. A., } \\
\text { Gowda, P. H., Schwartz, R. C., } \\
\text { Marek, G. W., \& Lamm, F. R. }\end{array}$ & $\begin{array}{l}\text { Modeling cotton growth and yield response } \\
\text { to irrigation practices for thermally limited } \\
\text { growing seasons in Kansas. }\end{array}$ & Irrig. mgmt. & https://doi.org/10.13031/trans.13877 \\
\hline $\begin{array}{l}\text { Bjorneberg, D. L., Ippolito, J. A., } \\
\text { King, B. A., Nouwakpo, S. K., } \\
\text { \& Koehn, A. C. }\end{array}$ & $\begin{array}{l}\text { Moving toward sustainable irrigation in a } \\
\text { southern Idaho irrigation project. }\end{array}$ & Water supply & https://doi.org/10.13031/trans.13955 \\
\hline $\begin{array}{l}\text { Butts, C. L., Sorensen, R. B., } \\
\text { \& Lamb, M. C. }\end{array}$ & $\begin{array}{l}\text { Irrigator Pro: Progression of a peanut irrigation } \\
\text { scheduling decision support system. }\end{array}$ & $\begin{array}{l}\text { Irrig. mgmt.; } \\
\text { humid region }\end{array}$ & https://doi.org/10.13031/aea.13909 \\
\hline $\begin{array}{l}\text { Cardenas, B., Migliaccio, K. W., } \\
\text { Dukes, M. D., Hahus, I., } \\
\text { \& Kruse, J. K. }\end{array}$ & $\begin{array}{c}\text { Irrigation savings from smart irrigation } \\
\text { technologies and a smartphone app } \\
\text { on turfgrass. }\end{array}$ & $\begin{array}{c}\text { Turf/landscape; } \\
\text { tech. and } \\
\text { innovation } \\
\end{array}$ & https://doi.org/10.13031/trans.13903 \\
\hline $\begin{array}{l}\text { Chávez, J. L., Torres-Rua, A. F., } \\
\text { Woldt, W. E., Zhang, H., } \\
\text { Robertson, C. C., Marek, G. W., } \\
\text {... \& Neale, C. M. }\end{array}$ & $\begin{array}{l}\text { A decade of unmanned aerial systems in } \\
\text { irrigated agriculture in the western U.S. }\end{array}$ & $\begin{array}{l}\text { Tech. and } \\
\text { innovation }\end{array}$ & https://doi.org/10.13031/aea.13941 \\
\hline Chiu, Y. L. J., \& Reba, M. L. & $\begin{array}{l}\text { Development of a wireless sensor network for } \\
\text { tracking flood irrigation management in } \\
\text { production-sized rice fields in the Mid-South. }\end{array}$ & $\begin{array}{l}\text { Tech. and } \\
\text { innovation; } \\
\text { humid region }\end{array}$ & https://doi.org/10.13031/aea.13962 \\
\hline Conger, S. L., \& Dukes, M. D. & $\begin{array}{l}\text { Evaluation of testing procedures for weather- } \\
\text { based irrigation controllers. }\end{array}$ & $\begin{array}{c}\text { Turf/landscape; } \\
\text { tech. and } \\
\text { innovation }\end{array}$ & https://doi.org/10.13031/trans.13926 \\
\hline Dukes, M. D. & $\begin{array}{l}\text { Two decades of smart irrigation controllers } \\
\text { in U.S. landscape irrigation. }\end{array}$ & $\begin{array}{c}\text { Turf/landscape; } \\
\text { tech. and } \\
\text { innovation } \\
\end{array}$ & https://doi.org/10.13031/trans.13930 \\
\hline $\begin{array}{l}\text { Evett, S. R., Marek, G. W., Colaizzi, P. D., } \\
\text { Brauer, D., \& Howell, T. A. }\end{array}$ & $\begin{array}{l}\text { Are crop coefficients for SDI different from } \\
\text { those for sprinkler irrigation application? }\end{array}$ & ET & https://doi.org/10.13031/trans.13920 \\
\hline $\begin{array}{l}\text { Evett, S. R., O’Shaughnessy, S. A., } \\
\text { Andrade, M. A., Colaizzi, P. D., } \\
\text { Schwartz, R. C., Schomberg, H. S., } \\
\text {... \& Sui, R. }\end{array}$ & $\begin{array}{c}\text { Theory and development of a VRI decision } \\
\text { support system: The USDA-ARS } \\
\text { ISSCADA approach. }\end{array}$ & $\begin{array}{l}\text { Irrig. systems; } \\
\text { tech. and } \\
\text { innovation }\end{array}$ & https://doi.org/10.13031/trans.13922 \\
\hline $\begin{array}{l}\text { Hashem, A. A., Engel, B. A., } \\
\text { Marek, G. W., Moorhead, J. E., } \\
\text { Flanagan, D. C., Rashad, M., } \\
\text {... \& Gowda, P. H. }\end{array}$ & $\begin{array}{c}\text { Evaluation of SWAT soil water estimation } \\
\text { accuracy using data from Indiana, Colorado, } \\
\text { and Texas. }\end{array}$ & Irrig. mgmt. & https://doi.org/10.13031/trans. 13910 \\
\hline Henry, C., Krutz, L., \& Mane, R. & $\begin{array}{l}\text { The Arkansas "most crop per drop" contest: } \\
\text { An innovative extension method to improve } \\
\text { irrigation water management adoption. }\end{array}$ & $\begin{array}{l}\text { Tech. and } \\
\text { innovation; } \\
\text { humid region }\end{array}$ & https://doi.org/10.13031/trans.13964 \\
\hline $\begin{array}{c}\text { Kelley, J., McCauley, D., } \\
\text { Alexander, G. A., Gray, W. F., } \\
\text { Siegfried, R., \& Oldroyd, H. J. }\end{array}$ & $\begin{array}{l}\text { Using machine learning to integrate on-farm } \\
\text { sensors and agro-meteorology networks } \\
\text { into site-specific decision support. }\end{array}$ & ET & https://doi.org/10.13031/trans.13917 \\
\hline $\begin{array}{l}\text { King, B. A., Shellie, K. C., } \\
\text { Tarkalson, D. D., Levin, A. D., } \\
\text { Sharma, V., \& Bjorneberg, D. L. }\end{array}$ & $\begin{array}{l}\text { Data-driven models for canopy temperature- } \\
\text { based irrigation scheduling. }\end{array}$ & Irrig. mgmt. & https://doi.org/10.13031/trans.13901 \\
\hline $\begin{array}{l}\text { Lamm, F. R., Colaizzi, P.D., } \\
\text { Sorensen, R. B., Bordovsky, J. P., } \\
\text { Dougherty, M., Balkcom, K., } \\
\text {... \& Peters, R. T. }\end{array}$ & $\begin{array}{c}\text { A } 2020 \text { vision of subsurface drip irrigation } \\
\text { in the U.S. }\end{array}$ & Irrig. systems & https://doi.org/10.13031/trans.14555 \\
\hline $\begin{array}{c}\text { Leib, B., Wright, W., Grant, T., } \\
\text { Haghverdi, A., Muchoki, D., } \\
\text { Vanchiasong, P., ... \& W Wszelaki, A. }\end{array}$ & $\begin{array}{l}\text { Rainwater harvesting with solar and gravity } \\
\text { powered irrigation for high tunnels. }\end{array}$ & Humid region & https://doi.org/10.13031/aea.13969 \\
\hline
\end{tabular}


Table 1 (continued). Summary of articles included in the 2021 ASABE Special Collection "Beyond 2020, Vision of the Future: Selected Papers from the 6th Decennial National Irrigation Symposium".

\begin{tabular}{|c|c|c|c|}
\hline Authors & Title & Key Topics & DOI \\
\hline $\begin{array}{c}\text { Lena, B. P., Ortiz, B. V., } \\
\text { Jiménez-Lópe, A. F., Sanz-Sáez, Á., } \\
\text { O’Shaughnessy, S. A., Durstock, M. K., } \\
\text { \& Pate, G. }\end{array}$ & $\begin{array}{l}\text { Evaluation of infrared canopy temperature } \\
\text { data in relation to soil water-based irrigation } \\
\text { scheduling in a humid subtropical climate. }\end{array}$ & $\begin{array}{l}\text { Tech. and } \\
\text { innovation; } \\
\text { humid region }\end{array}$ & https://doi.org/10.13031/trans.13912 \\
\hline $\begin{array}{l}\text { Lo, T. H., Pringle, H. C., } \\
\text { Rudnick, D. R., Bai, G., Krutz, L. J., } \\
\text { Gholson, D. M., \& Qiao, X. }\end{array}$ & $\begin{array}{l}\text { Within-field variability in granular matrix } \\
\text { sensor data and its implications for } \\
\text { irrigation scheduling. }\end{array}$ & $\begin{array}{l}\text { Tech. and } \\
\text { innovation; } \\
\text { humid region }\end{array}$ & https://doi.org/10.13031/aea.13918 \\
\hline $\begin{array}{l}\text { Marek, T. H., Porter, D., Howell, T. A., } \\
\text { Marek, G. W., \& Brauer, D. }\end{array}$ & $\begin{array}{c}\text { The impact and value of accurate evapotrans- } \\
\text { piration networks in Texas High Plains } \\
\text { production agriculture. }\end{array}$ & ET & https://doi.org/10.13031/aea.13913 \\
\hline $\begin{array}{l}\text { Marek, G. W., Marek, T. H., Evett, S. R., } \\
\text { Bell, J. M., Colaizzi, P. D., Brauer, D. K., } \\
\text { \& Howell, T. A. }\end{array}$ & $\begin{array}{l}\text { Comparison of lysimeter-derived crop coeffi- } \\
\text { cients for legacy and modern drought-tolerant } \\
\text { maize hybrids in the Texas High Plains. }\end{array}$ & ET & https://doi.org/10.13031/trans.13924 \\
\hline $\begin{array}{l}\text { O’Shaughnessy, S. A., Andrade, M. A., } \\
\text { Colaizzi, P. D., Workneh, F., Rush, C. M., } \\
\text { Evett, S. R., \& Kim, M. }\end{array}$ & $\begin{array}{l}\text { Irrigation management of potatoes using } \\
\text { sensor feedback: Texas High Plains. }\end{array}$ & $\begin{array}{l}\text { Irrig. systems; } \\
\text { tech. and } \\
\text { innovation }\end{array}$ & https://doi.org/10.13031/trans.13925 \\
\hline $\begin{array}{l}\text { Porter, D. O., Irmak, S., Lamm, F., } \\
\text { Marek, T., \& Rein, B. }\end{array}$ & $\begin{array}{l}\text { Challenges and opportunities for education } \\
\text { in irrigation engineering. }\end{array}$ & $\begin{array}{l}\text { Tech. and } \\
\text { innovation }\end{array}$ & https://doi.org/10.13031/trans.13943 \\
\hline Reba, M. L., \& Massey, J. H. & $\begin{array}{l}\text { Surface irrigation in the lower Mississippi } \\
\text { River basin: Trends and innovations. }\end{array}$ & $\begin{array}{l}\text { Irrig. systems; } \\
\text { humid region }\end{array}$ & https://doi.org/10.13031/trans.13970 \\
\hline $\begin{array}{l}\text { Reinhart, B. D., Frankenberger, J. R., } \\
\text { Hay, C. H., Bowling, L. B., } \\
\text { \& Hancock, B. G. }\end{array}$ & $\begin{array}{c}\text { Development and sensitivity analysis of an } \\
\text { online tool for evaluating drainage water } \\
\text { recycling decisions. }\end{array}$ & Humid region & https://doi.org/10.13031/trans.13900 \\
\hline $\begin{array}{l}\text { Rudnick, D. R., Stockton, M., } \\
\text { Taghvaeian, S., Warren, J., } \\
\text { Dukes, M. D., Kremen, A., } \\
\text {... \& Amosson, S. H. } \\
\end{array}$ & $\begin{array}{l}\text { Innovative extension methods in the U.S. to } \\
\text { promote irrigation water management. }\end{array}$ & $\begin{array}{l}\text { Tech. and } \\
\text { innovation }\end{array}$ & https://doi.org/10.13031/trans.13929 \\
\hline $\begin{array}{c}\text { Stone, K. C., Bauer, P. J., } \\
\text { O'Shaughnessy, S., } \\
\text { Andrade-Rodriguez, A., \& Evett, S. }\end{array}$ & $\begin{array}{l}\text { A variable-rate irrigation decision support } \\
\text { system for corn in the U.S. eastern } \\
\text { coastal plain. }\end{array}$ & $\begin{array}{l}\text { Irrig. systems; } \\
\text { tech. and } \\
\text { innovation }\end{array}$ & https://doi.org/10.13031/trans.13965 \\
\hline $\begin{array}{c}\text { Sui, R., O’Shaughnessy, S. A., } \\
\text { Evett, S. R., Andrade-Rodriguez, A., } \\
\text { \& Baggard, J. }\end{array}$ & $\begin{array}{l}\text { Evaluation of a decision support system for } \\
\text { variable-rate irrigation in a humid region. }\end{array}$ & $\begin{array}{l}\text { Irrig. systems; } \\
\text { tech. and } \\
\text { innovation } \\
\end{array}$ & https://doi.org/10.13031/trans.13904 \\
\hline $\begin{array}{l}\text { Taghvaeian, S., Andales, A. A., } \\
\text { Allen, L. N., Kisekka, I., } \\
\text { O’Shaughnessy, S. A., } \\
\text { Porter, D. O., ... \& Aguilar, J. } \\
\end{array}$ & $\begin{array}{c}\text { Irrigation scheduling for agriculture in the } \\
\text { United States: The progress made and } \\
\text { the path forward. }\end{array}$ & Irrig. mgmt. & https://doi.org/10.13031/trans.14110 \\
\hline $\begin{array}{c}\text { Trout, T. J., Howell, T. A., } \\
\text { English, M. J., \& Martin, D. L. }\end{array}$ & Deficit irrigation strategies for the western U.S. & Irrig. mgmt. & https://doi.org/10.13031/trans.14114 \\
\hline $\begin{array}{l}\text { Zamora-Re, M. I., Rath, S., } \\
\text { Dukes, M. D., \& Graham, W. }\end{array}$ & $\begin{array}{l}\text { Water and nitrogen budget dynamics for a } \\
\text { maize-peanut rotation in Florida. }\end{array}$ & $\begin{array}{l}\text { Irrig. mgmt.; } \\
\text { humid region }\end{array}$ & https://doi.org/10.13031/trans.13916 \\
\hline
\end{tabular}

factors), and these coefficients have varying accuracy, geographical applicability, and methodologies for their development and usage. Application of the FAO-56 dual crop coefficient method for determining ET and irrigation water requirements for large areas of the western U.S. (Idaho and Nevada) was discussed by Allen et al. (2020a). The products of this effort are used by state governments to manage water rights, water resource planning and design, and hydrologic assessment and modeling. The federal government has used the products for assessing the impacts of climate change on irrigation requirements. Key innovations of the products are the scaling of crop coefficients $\left(K_{C}\right)$ to thermal units (i.e., growing degree days, GDD) and the improvement in ET estimations during the dormant season. Similarly, a $K_{C}$ curve for sugar beet in eastern Colorado was improved by scaling with GDD and leaf area index (Andales et al., 2020) as compared to earlier published time-based $K_{C}$ values (Allen et al., 2007). The new $K_{C}$ curve improved estimates of soil water deficits and were incorporated into a cloud-based irrigation scheduling program called Water Irrigation Scheduler for Efficiency (WISE). In the Texas High Plains (Marek et al., 2020a), the maximum daily $K_{C}$ values for legacy and modern drought tolerant (DT) corn hybrids were found to be similar, but season length was shorter for the DT hybrids, thus affecting the shape of the $K_{C}$ curve. The authors pointed out that the published $K_{C}$ values were generally applicable, but their advance and decline throughout the season should be modified based on canopy growth and climate. In another Texas High Plains study (Evett et al., 2020a), the $K_{C}$ value for corn with subsurface drip irrigation (SDI) was only $83 \%$ to $89 \%$ of the value for mid-elevation spray application (MESA), and the authors concluded that SDI $K_{C}$ values should be decreased by $10 \%$ compared to sprinkler irrigation. They indicated similarity in SDI $K_{C}$ values to those that could be developed for surface drip irrigation when using full-cover plastic mulch.

Landscape coefficients $\left(K_{L}\right)$ are similar to $K_{C}$ but are used for natural and urban landscapes that often vary in composition (e.g., vegetation types, density, and ground cover), micro-climate (e.g., shading and light reflection by structures, fetch and wind, slope, reflected radiation aspects), and enduser practices. A multi-component decoupling method for $K_{L}$ was discussed in a comprehensive review of different $K_{L}$ methodologies (Allen et al., 2020b). The authors concluded that the ASABE Standard S623 methodology (ASABE, 2017) is simpler yet complementary to the IA methodology 
for $K_{L}$ (IA, 2003), but that either can be used to effectively estimate landscape water requirements.

On-farm irrigation scheduling requires accurate weather data and delivery of ET values through public and/or private weather station networks. These networks can be costly to install, operate, and maintain, and in some cases the lack of sufficient station density affects their effectiveness as a water management tool. One large and long-term system, the Texas High Plains ET Network, was estimated to save irrigated producers $\$ 22$ million annually through energy and water savings (Marek et al., 2020b). The authors also discussed the requirements and challenges of sustaining a successful network and the associated costs, noting that the societal benefits can extend well beyond the agricultural sector. Because high-quality weather stations are expensive and often are sparsely located, there can be limitations on their use for on-farm irrigation scheduling. Research using data from agricultural fields in Oregon and California (Kelley et al., 2020) evaluated the use of machine learning combining regional weather station data with data from a few inexpensive on-farm sensors to improve site-specific irrigation management. The authors concluded that such machine learning techniques could be considerably improved if mobile highquality weather stations could be co-located at the field site for a short duration (e.g., 14 days).

These seven studies illustrate the continued progress in ET estimation and its implementation for irrigation water management, and they augment the six ET-related papers in the earlier ASABE Special Collections (Dukes et al., 2012; Lamm et al., 2016).

\section{IRRIGATION MANAGEMENT (STRATEGIES, SCHEDULING, AND MODELING)}

Ultimately, the success of any irrigation system or irrigated farming operation is constrained by the irrigation management, with a heavy emphasis on the human aspect. The strategies are often seasonal or longer-term and may have various goals (e.g., maximum yield, improved crop quality, water conservation, greatest net return) that may interact and also may be chosen by the producer or governed by some external constraint. Irrigation scheduling is typically defined as determining when and how much to irrigate, and decisions are often made in the short-term (e.g., daily or sometimes even more frequently). Modeling can be used to evaluate both strategies and irrigation scheduling practices. Eight journal articles for this ASABE Special Collection were closely related to this topic, with one article (Andales et al., 2020) previously discussed in the Evapotranspiration section.

Managed deficit irrigation is sometimes used as an irrigation strategy when the water resource is limited (e.g., hydrologic or institutional constraints) or when the water is expensive and the strategic goal is to maximize net returns for the cropped land. A modeling framework for deficit irrigation in the western U.S. was described by Trout et al. (2020) for two deficit irrigation conditions (i.e., land-limited and water-limited constraints). The models incorporated both biophysical and economic relationships to maximize net returns. The authors pointed out that the sensitivity of net returns to deficit irrigation can be decreased with judicious planning for production inputs and costs. In addition, even when a deficit irrigation strategy reduces overall crop production, it can reduce the chance of crop failure and help to ensure at least some profitability.

Progress in irrigation scheduling in the U.S. was the topic of three Special Collection journal articles (Butts et al., 2020; King et al., 2020; Taghvaeian et al., 2020). The progression of Irrigator Pro, an irrigation scheduling decision support system (DSS), was discussed by Butts et al. (2020). This DSS began as an expert system and checkbook-based scheduler for peanuts and was first implemented on desktop personal computers in 1995. Since then, it has been further developed with support for corn and cotton irrigation scheduling and availability on mobile web-based platforms incorporating available weather data and soil water data streams. Further advances are planned to incorporate additional data streams, such as soil water data from capacitance probes.

Improved prediction of the crop water stress index (CWSI; Idso et al., 1981; Jackson et al., 1981) using artificial neural network (ANN) modeling for sugar beet and wine grapes was reported by King et al. (2020). They concluded that the improved estimation of the reference temperatures used in the CWSI calculation allowed effective usage of CWSI for these two crops in the study region, provided that measurements under wet canopy or low solar radiation are disregarded.

A review of agricultural irrigation scheduling progress within the last decade in the U.S., its current status, and its anticipated future was provided by Taghvaeian et al. (2020). USDA-NASS survey data were used to illustrate that many irrigators continue to use qualitative measures to inform irrigation scheduling decisions, rather than quantitative, science-based tools. Some improvements have been made in adoption in science-based scheduling, particularly with advances in soil water sensors and the ability to collect and analyze the data. Improvements in decision support systems, plant and soil sensors, and the internet of things (IoT) should continue to increase the adoption rate of irrigation scheduling but would still benefit from university, state and federal agency, and private technical support for training and implementation. The authors concluded that there are important opportunities to develop integrated irrigation scheduling strategies combining the various approaches (i.e., soil, plant, and weather-based modeling) that are more robust than existing methods.

Cotton requires less irrigation than corn and thus has become an irrigated crop of interest in western Kansas despite the limited thermal units available for production. Modeling was used to examine the effects of crop emergence date, irrigation capacity, and irrigation application period on cotton production in three western Kansas locations (Baumhardt et al., 2020). Earlier emergence generally increased yield and water productivity. Greater irrigation capacity usually increased yield, but extending the irrigation period beyond four to six weeks was not beneficial. The authors concluded that there were some opportunities for cotton production in southwest Kansas, but not for west central and northwest Kansas.

Modeling and field experimental data were used to evaluate water and nitrogen dynamics in a corn-peanut rotation in Florida (Zamora-Re et al., 2020). DSSAT 4.7 (Hoogenboom et al., 2019) modeling accurately simulated field data 
for three irrigation rates and three $\mathrm{N}$ fertilizer rates. The simulations demonstrated that $\mathrm{N}$ leaching could be greatly reduced $(\sim 37 \%)$ by limiting $\mathrm{N}$ application to $247 \mathrm{~kg} \mathrm{ha}^{-1}$ and using sensor-based irrigation scheduling as compared to conventional practices.

The Soil and Water Assessment Tool (SWAT) was used to estimate soil water at three locations in the U.S. (northeastern Indiana, Texas High Plains, and northeastern Colorado) for periods ranging from one to ten years (Hashem et al., 2020). The soil water simulations at all three sites were deemed unacceptable for use in irrigation management. The authors suggested that the SWAT soil water algorithms did not accurately simulate soil water redistribution between layers for plant water demand and that there was also uncertainty in soil parameterization.

Irrigation management continues to be a major topic of research and extension efforts, as demonstrated by these seven studies, and is likely to continue to be so in the future. The aforementioned earlier ASABE Special Collections (Dukes et al., 2012; Lamm et al., 2016) had a combined total of five papers related to this topic.

\section{IRRIGATION SYSTEMS (SPRINKLER, SURFACE GRAVITY, AND MICROIRRIGATION)}

Although irrigation systems by themselves cannot manage or conserve water, their appropriate design, operation, and management are key factors in optimizing the use of irrigation water. Each of the major system types (i.e., sprinkler, surface gravity, and microirrigation) require their own appropriate design, operation, and management. Eight journal articles for this ASABE Special Collection were related to this topic.

During the last decade, the USDA-ARS has worked extensively on a variable-rate irrigation (VRI) DSS implemented in its patented Irrigation Scheduling Supervisory Control and Data Acquisition (ISSCADA) system (Evett et al., 2014). The theory and development of the DSS was discussed by Evett et al. (2020b). Both plant and soil water sensors and research-based algorithms were integrated into the DSS and automated irrigation control system. Research efforts at several USDA-ARS sites were important, culminating in the DSS. The sensor-based DSS software developed by the USDA-ARS was named ARSPivot, and the software development and its application were discussed by Andrade et al. (2020a, 2020b). Using a graphical user interface (GUI), ARSPivot assists in the process of setting up and reviewing irrigation prescriptions that can be generated automatically based on sensor feedback.

Irrigated potato production on the Texas High Plains was evaluated with manual irrigation and ISSCADA-controlled irrigation in a two-year field study (O'Shaughnessy et al., 2020). The authors reported that ISSCADA-controlled irrigation resulted in fewer irrigation events in a drier growing season (2018) and in similar or better potato yields in a wetter season (2019). They concluded that further research was warranted to develop better soil water criteria for triggering ISSCADA-controlled irrigation. Irrigated soybean production was evaluated with ISSCADA-controlled irrigation and a soil electrical conductivity (EC) based method in Mississippi (Sui et al., 2020), and the authors found that the
ISSCADA method reduced irrigation water use and increased irrigation water productivity. VRI for corn production on the U.S. Eastern Coastal Plain was evaluated for two different implementations of the ISSCADA system (Stone et al., 2020). The authors reported greater corn yields and less irrigation requirements for a hybrid implementation of ISSCADA that included soil water depletion criteria as compared to the standard ISSCADA. Research to further develop and implement the DSS continues at the USDA-ARS.

As discussed earlier, the Mid-South region of the U.S. has experienced much growth in irrigated land area, mostly with surface irrigation. A review of surface irrigation in the lower Mississippi River basin was provided by Reba and Massey (2020). Noting that $90 \%$ of the irrigation water applied to 4 Mha of cropland is from groundwater, they detailed ongoing efforts to address the overdraft of the alluvial aquifer (i.e., Mississippi River source). Irrigation innovations include system improvements (e.g., land grading, pump automation, improved in-field application), management strategies (e.g., changes to rice flooding), and institutional efforts (e.g., flowmeter requirements and water permits).

The use of subsurface drip irrigation (SDI) continues to increase in the U.S. and has been the subject of a considerable amount of research during the last decade, as discussed in a comprehensive review by Lamm et al. (2021). Research from 2010 through 2020 within the U.S. for SDI cotton, grain and oilseed crops, horticultural, forage, and turf crops is summarized in their review. Persistent challenges (e.g., rodent damage, germination and crop establishment, clogging) still exist, but opportunities for further adoption also exist (e.g., increased crop yield or quality, increased water productivity, use of effluents, reduction in greenhouse gas emissions, integrated and intensified crop production).

Integrated use of advanced irrigation management strategies and/or other irrigation technologies (e.g., crop physiology algorithms, cultivar selection, cultural practices, agrochemical applications, weather monitoring, soil and plant water sensors, irrigation control systems, etc.) with these advances in the design, operation, and management of irrigation systems is likely to continue to be a fruitful research topic in the coming decade. These eight journal articles in this ASABE Special Collection are illustrative of just some of the progress of the last decade. The aforementioned earlier ASABE Special Collections (Dukes et al., 2012; Lamm et al., 2016) had a combined total of 13 papers related to this topic.

\section{TURF AND LANDSCAPE IRRIGATION}

Irrigation for turf and landscape is a major use of municipal water in the U.S. and continues to be scrutinized by water planners and regulators looking for additional ways to conserve water. Four journal articles in this Special Collection were related to turf and landscape irrigation, three concerning irrigation controllers (Cardenas et al., 2020; Conger and Dukes, 2020; Dukes, 2020), and the other article (Allen et al., 2020b) was previously discussed in the Evapotranspiration section.

A comprehensive review of smart irrigation controllers for turf and landscape irrigation was discussed by Dukes (2020). When irrigation savings were reported (12 of 17 studies), the average savings in research plots was $51 \%$, 
but savings for residential systems averaged only $30 \%$. In the five studies reporting increased irrigation with smart controllers, the primary reasons appeared to be controller usage at sites where irrigation needs were low and in cases where the controller programming was not optimized. The importance of human factors was documented, and it was concluded that consumer education remains a key factor in achieving water conservation.

A two-year research study in Florida with smart irrigation technologies and a smart phone application (SP) was discussed by Cardenas et al. (2020). Irrigation treatments based on the advanced technologies [i.e., soil moisture sensor (SMS), estimated ET, or SP] saved approximately 30\% to $65 \%$ more water than traditional time-based irrigation control. The reasons for water savings with the advanced technologies varied, with fewer irrigation events attributed to SMS, reduced irrigation depths for ET, and a combination of the two reasons for SP. The authors reported that the economic payback for the advanced technologies ranged from 0 to 12 months.

The performance of the Smart Water Application Technologies testing protocol for weather-based irrigation controllers for turf and landscape in Florida was evaluated by Conger and Dukes (2020). They found deficiencies in the reproducibility and transferability of results. Some of the deficiencies were related to inadequate documentation of the protocol, controller setup and programming, order of operations, and availability of weather data. They suggested potential improvements to the testing protocol.

These three articles along with the fourth article discussed earlier (Allen et al., 2020b) highlight some of the research progress in turf and landscape irrigation since the 5th Decennial NIS in 2010. The aforementioned earlier ASABE Special Collections (Dukes et al., 2012; Lamm et al., 2016) had a combined total of eight papers related to this topic.

\section{TECHNOLOGY AND INNOVATION (SENSORS, TECHNOLOGY USAGE AND ADOPTION, EXTENSION/EDUCATION)}

Advances in irrigation technology [e.g., sensors, irrigation controllers, unmanned aerial systems (UAS)] and its adoption and the availability of innovative research, extension, and education programs in irrigation science were key factors in the progress of irrigation management in the U.S. during the past decade. Seven journal articles from this ASABE Special Collection are discussed in this section, but ten additional articles (Andrade et al., 2020a, 2020b; Cardenas et al., 2020; Conger and Dukes, 2020; Dukes, 2020; Evett et al., 2020b; Lena et al., 2020; O'Shaughnessy et al., 2020; Stone et al., 2020; Sui et al., 2020) discussed in other sections of this article easily overlap with this topic.

The use of soil water sensors for scheduling agricultural irrigation is growing in the U.S. The within-field variability in granular matrix soil water sensor data was examined in a field study in Mississippi (Lo et al., 2020). The authors found that variability was greater for individual depths than for the complete soil profile, and that variability increased as the soil water decreased. They proposed a probabilistic conceptual framework to interpret the variability in the soil water data. They concluded that if the irrigation scheduling goal is to maintain adequate soil water for a specific fraction of the irrigated field, then the advantage of adding additional soil water sensors may not be as useful as anticipated.

The development of a wireless sensor network (WSN) for monitoring remote rice production fields in the Mid-South U.S. was discussed by Chiu and Reba (2020). The WSN in this implementation included data from soil water sensors and water level data (i.e., depth in flooded rice fields) obtained with ultrasonic sensors. The authors found significant relationships between automated and manual measurements of water level data for three different irrigated rice production methods that are used in the Mid-South. Problems with field installation and maintenance of the water depth sensors and potential solutions were discussed. The authors concluded that the WSN with various sensors and appropriate installation and maintenance could provide real-time information useful for management of irrigated rice production.

Advances in the last decade in the use of UAS for irrigation management in the western U.S. were the subject of a review (Chávez et al., 2020). The authors found that, despite the advances, further improvements are needed in UAS platforms, sensor integration, processing software, and government regulation. They concluded that further advances in UAS adoption and implementation for irrigation scheduling could be augmented through better integration of multiple sensor data streams (i.e., UAS, ground-based, satellite sensors). As these data streams are becoming more readily available, data science will be a key factor in processing, analysis, and interpretation of such large volumes of data.

The increased water productivity for U.S. cotton during the last 40 years was attributed to a combination of improved irrigation systems and associated technologies, irrigation scheduling and management, and changes in cultivars in a comprehensive review (Barnes et al., 2020). Irrigation systems and adoption of associated technology varied across the southern cotton production regions, with local climate, water availability, soils, and topography having an important influence. The authors reported 2018 USDA-NASS data indicating that nearly $60 \%$ of the irrigated cotton in the U.S. uses sprinkler irrigation and that approximately $36 \%$ of the 4.1 Mha of cotton nationwide is irrigated. They concluded that water productivity improvements for cotton during the last 40 years must continue due to stressed water resources and climate variability, and will continue due to further advances in irrigation systems and associated technologies and through genetic gains.

The challenges and opportunities for education in irrigation engineering were discussed in a perspective article by Porter et al. (2020). They found that declining enrollments and a declining number of university degree programs were having a negative impact on the availability of irrigation engineering expertise. While shorter-term technical degree and certificate programs can fill some of these gaps, it is important that qualified irrigation engineers be developed to address present and emerging national and international challenges in irrigated agriculture. Extension and other education programs are continuing to evolve to provide the skills needed by end-users and are often available in both ondemand internet-based and social media-based formats. The authors concluded that current knowledge gaps and research time lags can cause restlessness among some end-users and 
that the problem increases the potential for misimplementation of technologies and products that have little scientific basis in fact.

An innovative extension method in Arkansas, the "most crop per drop" contest, was described by Henry et al. (2020). The contest promoted the adoption of surge irrigation, soil water monitoring, computerized hole selection for poly-pipe furrow irrigation, and multiple inlet rice irrigation. Using a modified calculation of water use efficiency (WUE) as a metric, the authors found that the contest winners (i.e., those with the greatest WUE) did not always have the greatest corn, soybean, or rice yields. Cash prizes and donated industry products averaging $\$ 60,000$ per year were presented to the contest winners at an Arkansas conservation conference. The authors found that contest participants increased adoption of computerized hole selection by $33 \%$, surge irrigation by $28 \%$, and soil water monitoring by $51 \%$, and concluded that all contest participants were "winners" through improved water management.

Innovative extension programs in the Great Plains and Southeast U.S. to promote improved irrigation management were described by Rudnick et al. (2020). They reported that university extension is serving a larger number of irrigated farms as technology becomes more complex and the stress on water resources increases. They also noted that there has been a transition away from typical lectures and field tours for information delivery and knowledge transfer. Newer extension programs have focused on experiential learning, development of practitioner networks, and industry participation. The ability of practitioners to interact with each other, with university and agency staff, and with industry seems to promote individual responsibility and the sustainability of adopted practices.

The seven papers discussed in this section and the ten related papers discussed in other sections of this article comprise a sizable body of important research and extension efforts in technology and innovation. The aforementioned earlier ASABE Special Collections (Dukes et al., 2012; Lamm et al., 2016) had a combined total of twelve papers related to this topic.

\section{IRRIGATION IN THE HUMID REGION}

Nearly $30 \%$ of the total irrigated land area in the U.S. is located in the eastern humid states, and the area continues to increase (USDA-NASS, 2018). Overall, eight journal articles for this ASABE Special Collection were related to agricultural irrigation in the humid region, with three articles specifically discussed in this section (Leib et al., 2020; Lena et al., 2020; Reinhart et al., 2020). The other five articles were discussed in the Technology and Innovation section (Chiu and Reba, 2020; Henry, et al., 2020; Lo et al., 2020), the Irrigation Systems section (Reba and Massey, 2020), and the Irrigation Management section (Zamora-Re et al., 2020).

Plant water stress criteria [CWSI and temperature-time threshold (TTT)] were evaluated in a humid subtropical climate for irrigated corn production in Alabama (Lena et al., 2020). In a season with more sparse rainfall events, both CWSI and corn yield were significantly affected by irrigation treatment, but not so in a season with more evenly distributed rainfall. The authors concluded that further study was needed to develop CWSI threshold values for irrigated corn in this region. They found that the TTT method did not work well for irrigation management in this region, whether or not the additional limiting relative humidity factor was considered.

Rainwater harvesting (RWH) was sufficient to meet irrigation needs for high tunnels (i.e., simple greenhouse structures using plastic film) in Tennessee (Leib et al., 2020) in a comparison of three different RWH systems (gravity flow, solar transfer pumping, and solar battery-powered pumping). The authors concluded that the costs of the three tested RWH systems were not competitive with the cost of using alternative water sources. Other potential RWH systems with lower initial costs were identified but remain untested.

Combining tile drainage and subirrigation is gaining interest in the midwestern U.S. and is termed drainage water recycling (DWR). An open-source online software tool (Evaluating Drainage Water Recycling Decisions, EDWRD) was developed to evaluate the potential irrigation and water quality benefits (Reinhart et al., 2020). Global sensitivity analysis indicated that the model was most sensitive to the input parameters controlling total available water.

These three articles along with the other five articles discussed in other sections of this article demonstrate just some of the breadth of irrigation research and extension activities occurring in the humid region. Although agriculture irrigation in the humid region was not a specific topic in the earlier ASABE Special Collections (Dukes et al., 2012; Lamm et al., 2016), four journal articles in those earlier collections would fit this topic.

\section{WATER SUPPLY}

In the western U.S., irrigation development was often achieved through a combination of private and public partnership. A case study of the Twin Falls Canal Company (TFCC), which began delivering water in Idaho in 1905, was discussed by Bjorneberg et al. (2020). They reported the early struggles of the TFCC (e.g., financial struggles, waterlogged soils) and the current challenges (e.g., chronic erosion from furrow irrigation, excessive nutrient losses in irrigation return flows). Although water quality of return flows has improved greatly in the last 30 years, more can be done to further improve water quality in the Snake River. The presence of six hydroelectric facilities on the TFCC improves the long-term viability of the project. There were no journal articles closely related to water supply issues in the earlier ASABE Special Collections.

\section{Conclusions}

The irrigated land area in the U.S. appears to have grown slightly in the last decade, but the top ten states have seen a slight decline $(\sim 2 \%)$ in land area, while the bottom 40 states have increased their irrigated land area $(\sim 13 \%)$. Irrigation in the primary Mid-South states adjacent to the Mississippi River now totals $4 \mathrm{Mha}$, and the irrigated land area in the humid eastern U.S. is $36 \%$ of the total irrigated land area. Pressurized irrigation (i.e., sprinkler and microirrigation) comprises about $65 \%$ of the total irrigated area, and the surface gravity irrigated land area continues to decline. 
At the time of this writing, it is anticipated that approximately 80 papers will be presented at the 6th Decennial NIS, scheduled for December 2021 in San Diego, California. This total includes 36 journal articles published in 2020 and 2021 as part of an ASABE Special Collection. These 36 articles are described in this introductory article. This Special Collection is the largest thus far in ASABE history and includes nine review articles, 24 research articles, one research brief, and two perspective articles. The progress in irrigation research and extension in the last decade and its current status in the U.S. suggest a good vision for the future of irrigation beyond 2020 .

\section{ACKNOWLEDGEMENTS}

Contribution No. 21-240-D from the Kansas Agricultural Experiment Station. This work was supported by the USDA National Institute of Food and Agriculture (Hatch Project 1019848); by the USDA-ARS Ogallala Aquifer Program, a consortium between the USDA-ARS, Kansas State University, Texas A\&M AgriLife Research, Texas A\&M AgriLife Extension, Texas Tech University, and West Texas A\&M University; and by USDA-ARS National Program 211, Water Availability and Watershed Management.

\section{REFERENCES}

Allen, R. G., Dukes, M. D., Snyder, R. L., Kjelgren, R., \& Kilic, A. (2020b). A review of landscape water requirements using a multicomponent landscape coefficient. Trans. ASABE, 63(6), 2039-2058. https://doi.org/10.13031/trans.13948

Allen, R. G., Pereira, L. S., Raes, D., \& Smith, M. (1998). Crop evapotranspiration: Guidelines for computing crop water requirements. Irrigation and Drainage Paper No. 56. Rome, Italy: United Nations FAO.

Allen, R. G., Robison, C. W., Huntington, J., Wright, J. L., \& Kilic, A. (2020a). Applying the FAO-56 dual $K_{C}$ method for irrigation water requirements over large areas of the western U.S. Trans. ASABE, 63(6), 2059-2081. https://doi.org/10.13031/trans.13933

Allen, R. G., Walter, I. A., Elliott, R. G., Howell, T. A., Itenfisu, D., Jensen, M. E., \& Snyder, R. L. (2005). The ASCE standardized reference evapotranspiration equation. Reston, VA: ASCE. https://doi.org/10.1061/9780784408056

Allen, R. G., Wright, J. L., Pruitt, W. O., Pereira, L. S., \& Jensen, M. E. (2007). Chapter 8. Water requirements. In G. J. Hoffman, R. G. Evans, M. E. Jensen, D. L. Martin, \& R. L. Elliott (Eds.), Design and operation of farm irrigation systems (2nd Ed., pp. 208-288). St. Joseph, MI: ASABE. https://doi.org/10.13031/2013.23691

Andales, A. A., Bartlett, A. C., Bauder, T. A., \& Wardle, E. M. (2020). Adapting a cloud-based irrigation scheduler for sugar beets in the High Plains. Appl. Eng. Agric., 36(4), 479-488. https://doi.org/10.13031/aea.13902

Andrade, M. A., O'Shaughnessy, S. A., \& Evett, S. R. (2020a). ARSPivot, a sensor-based decision support software for variable-rate irrigation center pivot systems: Part A. Development. Trans. ASABE, 63(5), 1521-1533. https://doi.org/10.13031/trans.13907

Andrade, M. A., O’Shaughnessy, S. A., \& Evett, S. R. (2020b). ARSPivot, a sensor-based decision support software for variable-rate irrigation center pivot systems: Part B. Application. Trans. ASABE, 63(5), 1535-1547. https://doi.org/10.13031/trans.13908

ASABE. (2017). S623.1: Determining landscape plant water demands. St. Joseph, MI: ASABE.
Barnes, E. M., Campbell, B. T., Vellidis, G., Porter, W., Payero, J., Leib, B., ... Thorp, K. (2020). Forty years of increasing cotton's water productivity and why the trend will continue. Appl. Eng. Agric., 36(4), 457-478. https://doi.org/10.13031/aea.13911

Baumhardt, R. L., Haag, L. A., Gowda, P. H., Schwartz, R. C., Marek, G. W., \& Lamm, F. R. (2020). Modeling cotton growth and yield response to irrigation practices for thermally limited growing seasons in Kansas. Trans. ASABE, 64(1), 1-12. https://doi.org/10.13031/trans.13877

Bjorneberg, D. L., Ippolito, J. A., King, B. A., Nouwakpo, S. K., \& Koehn, A. C. (2020). Moving toward sustainable irrigation in a southern Idaho irrigation project. Trans. ASABE, 63(5), 14411449. https://doi.org/10.13031/trans.13955

Butts, C. L., Sorensen, R. B., \& Lamb, M. C. (2020). Irrigator Pro: Progression of a peanut irrigation scheduling decision support system. Appl. Eng. Agric., 36(5), 785-795. https://doi.org/10.13031/aea.13909

Cardenas, B., Migliaccio, K. W., Dukes, M. D., Hahus, I., \& Kruse, J. K. (2020). Irrigation savings from smart irrigation technologies and a smartphone app on turfgrass. Trans. ASABE, 63(6), 1697-1709. https://doi.org/10.13031/trans.13903

Chávez, J. L., Torres-Rua, A. F., Woldt, W. E., Zhang, H., Robertson, C. C., Marek, G. W., ... Neale, C. M. (2020). A decade of unmanned aerial systems in irrigated agriculture in the Western U.S. Appl. Eng. Agric., 36(4), 423-436. https://doi.org/10.13031/aea.13941

Chiu, Y.-L. J., \& Reba, M. L. (2020). Development of a wireless sensor network for tracking flood irrigation management in production-sized rice fields in the mid-south. Appl. Eng. Agric., 36(5), 703-715. https://doi.org/10.13031/aea.13962

Conger, S. L., \& Dukes, M. D. (2020). Evaluation of testing procedures for weather-based irrigation controllers. Trans. $A S A B E$, 63(5), 1277-1287. https://doi.org/10.13031/trans.13926

Dukes, M. D. (2020). Two decades of smart irrigation controllers in U.S. landscape irrigation. Trans. ASABE, 63(5), 1593-1601. https://doi.org/10.13031/trans.13930

Dukes, M. D., Bjorneberg, D. L., \& Klocke, N. L. (2012). Advances in irrigation: Select works from the 2010 Decennial Irrigation Symposium. Trans. ASABE, 55(2), 477-482. https://doi.org/10.13031/2013.41398

Evett, S. R., Marek, G. W., Colaizzi, P. D., Brauer, D., \& Howell, T. A. (2020a). Are crop coefficients for SDI different from those for sprinkler irrigation application? Trans. ASABE, 63(5), 12331242. https://doi.org/10.13031/trans. 13920

Evett, S. R., O'Shaughnessy, S. A., \& Peters, R. T. (2014). Irrigation scheduling and supervisory control data acquisition system for moving and static irrigation systems. U.S. Patent No. $8,924,031 \mathrm{~B} 1$.

Evett, S. R., O’Shaughnessy, S. A., Andrade, M. A., Colaizzi, P. D., Schwartz, R. C., Schomberg, H. S., ... Sui, R. (2020b). Theory and development of a VRI decision support system: The USDAARS ISSCADA approach. Trans. ASABE, 63(5), 1507-1519. https://doi.org/10.13031/trans.13922

Hashem, A. A., Engel, B. A., Marek, G. W., Moorhead, J. E., Flanagan, D. C., Rashad, M., ... Gowda, P. H. (2020). Evaluation of SWAT soil water estimation accuracy using data from Indiana, Colorado, and Texas. Trans. ASABE, 63(6), 18271843. https://doi.org/10.13031/trans. 13910

Henry, C. G., Krutz, L. J., Mane, R., \& Simpson, G. D. (2020). The Arkansas "most crop per drop" contest: An innovative extension method to improve irrigation water management adoption. Trans. ASABE, 63(6), 2083-2088. https://doi.org/10.13031/trans.13964

Hoogenboom, G., Porter, C. H., Shelia, V., Boote, K. J., Singh, U., White, J. W., \& Jones, J. W. (2019). Decision Support System 
for Agrotechnology Transfer (DSSAT). Gainesville, FL: DSSAT Foundation.

IA. (2003). Landscape irrigation scheduling and water management: Practices guidelines. Falls Church, VA: Irrigation Association. Retrieved from http://www.irrigation.org/uploadedFiles/Resources/BMP_Revise d_12-2010.pdflast

Idso, S. B., Jackson, R. D., Pinter, P. J., Reginato, R. J., \& Hatfield, J. L. (1981). Normalizing the stress-degree-day parameter for environmental variability. Agric. Meteorol., 24, 45-55. https://doi.org/10.1016/0002-1571(81)90032-7

Jackson, R. D., Idso, S. B., Reginato, R. J., \& Pinter Jr, P. J. (1981). Canopy temperature as a crop water stress indicator. Water Resour. Res., 17(4), 1133-1138. https://doi.org/10.1029/WR017i004p01133

Kelley, J., McCauley, D., Alexander, G. A., Gray, W. F., Siegfried, R., \& Oldroyd, H. J. (2020). Using machine learning to integrate on-farm sensors and agro-meteorology networks into sitespecific decision support. Trans. ASABE, 63(5), 1427-1439. https://doi.org/10.13031/trans.13917

King, B. A., Shellie, K. C., Tarkalson, D. D., Levin, A. D., Sharma, V., \& Bjorneberg, D. L. (2020). Data-driven models for canopy temperature-based irrigation scheduling. Trans. ASABE, 63(5), 1579-1592. https://doi.org/10.13031/trans.13901

Lamm, F. R., Colaizzi, P. D., Sorensen, R. B., Bordovsky, J. P., Dougherty, M., Balkcom, K., ... \& Peters, R. T. (2021). A 2020 vision of subsurface drip irrigation in the U.S. Trans. ASABE, 64(4), (in press). https://doi.org/10.13031/trans. 14555

Lamm, F. R., Stone, K. C., Dukes, M. D., Howell Sr, T. A., Robbins Jr, J. W., \& Mecham, B. Q. (2016). Emerging technologies for sustainable irrigation: Selected papers from the 2015 ASABE and IA Irrigation Symposium. Trans. ASABE, 59(1), 155-161. https://doi.org/10.13031/trans.59.11706

Leib, B., Wright, W., Grant, T., Haghverdi, A., Muchoki, D., Vanchiasong, P., ... Wszelaki, A. (2020). Rainwater harvesting with solar and gravity powered irrigation for high tunnels. Appl. Eng. Agric., 36(4), 489-498. https://doi.org/10.13031/aea.13969

Lena, B. P., Ortiz, B. V., Jiménez-Lópe, A. F., Sanz-Sáez, Á., O'Shaughnessy, S. A., Durstock, M. K., \& Pate, G. (2020). Evaluation of infrared canopy temperature data in relation to soil water-based irrigation scheduling in a humid subtropical climate. Trans. ASABE, 63(5), 1217-1231. https://doi.org/10.13031/trans.13912

Lo, T. H., Pringle, H. C., Rudnick, D. R., Bai, G., Krutz, L. J., Gholson, D. M., \& Qiao, X. (2020). Within-field variability in granular matrix sensor data and its implications for irrigation scheduling. Appl. Eng. Agric., 36(4), 437-449. https://oi.org/10.13031/aea.13918

Marek, G. W., Marek, T. H., Evett, S. R., Bell, J. M., Colaizzi, P. D., Brauer, D. K., \& Howell, T. A. (2020a). Comparison of lysimeter-derived crop coefficients for legacy and modern drought-tolerant maize hybrids in the Texas High Plains. Trans. ASABE, 63(5), 1243-1257. https://doi.org/10.13031/trans.13924

Marek, T. H., Porter, D., Howell, T. A., Marek, G. W., \& Brauer, D. (2020b). The impact and value of accurate evapotranspiration networks in Texas High Plains production agriculture. Appl. Eng. Agric., 36(4), 451-455. https://doi.org/10.13031/aea.13913

O'Shaughnessy, S. A., Andrade, M. A., Colaizzi, P. D., Workneh, F., Rush, C. M., Evett, S. R., \& Kim, M. (2020). Irrigation management of potatoes using sensor feedback: Texas High Plains. Trans. ASABE, 63(5), 1259-1276. https://doi.org/10.13031/trans.13925

Porter, D. O., Irmak, S., Lamm, F., Marek, T., \& Rein, B. (2020). Challenges and opportunities for education in irrigation engineering. Trans. ASABE, 63(5), 1289-1294. https://doi.org/10.13031/trans.13943
Reba, M. L., \& Massey, J. H. (2020). Surface irrigation in the lower Mississippi River basin: Trends and innovations. Trans. ASABE, 63(5), 1305-1314. https://doi.org/10.13031/trans.13970

Reinhart, B. D., Frankenberger, J. R., Hay, C. H., Bowling, L. C., \& Hancock, B. G. (2020). Development and sensitivity analysis of an online tool for evaluating drainage water recycling decisions. Trans. ASABE, 63(6), 1991-2002. https://doi.org/10.13031/trans. 13900

Rudnick, D. R., Stockton, M., Taghvaeian, S., Warren, J., Dukes, M. D., Kremen, A., ... Amosson, S. H. (2020). Innovative extension methods in the U.S. to promote irrigation water management. Trans. ASABE, 63(5), 1549-1558. https://doi.org/10.13031/trans.13929

Stone, K. C., Bauer, P. J., O’Shaughnessy, S., Andrade-Rodriguez, A., \& Evett, S. (2020). A variable-rate irrigation decision support system for corn in the U.S. Eastern Coastal Plain. Trans. ASABE, 63(5), 1295-1303. https://doi.org/10.13031/trans.13965

Sui, R., O’Shaughnessy, S. A., Evett, S. R., Andrade-Rodriguez, A., \& Baggard, J. (2020). Evaluation of a decision support system for variable-rate irrigation in a humid region. Trans. ASABE, 63(5), 1207-1215. https://doi.org/10.13031/trans.13904

Taghvaeian, S., Andales, A. A., Allen, L. N., Kisekka, I., O'Shaughnessy, S. A., Porter, D. O., ... Aguilar, J. (2020). Irrigation scheduling for agriculture in the United States: The progress made and the path forward. Trans. ASABE, 63(5), 1603-1618. https://doi.org/10.13031/trans.14110

Trout, T. J., Howell, T. A., English, M. J., \& Martin, D. L. (2020). Deficit irrigation strategies for the western U.S. Trans. ASABE, 63(6), 1813-1825. https://doi.org/10.13031/trans.14114

USDA-NASS. (1994). Farm and ranch irrigation survey (1994). 1992 Census of Agriculture, Vol. 3, Special Studies, Part 3 (AC92-SS-1). Washington, DC: USDA National Agricultural Statistics Service.

USDA-NASS. (2004). Farm and ranch irrigation survey (2003). 2002 Census of Agriculture, Vol. 3, Special Studies, Part 1 (AC02-SS-1). Washington, DC: USDA National Agricultural Statistics Service.

USDA-NASS. (2010). Farm and ranch irrigation survey (2008). 2007 Census of Agriculture, Vol. 3, Special Studies, Part 1 (AC07-SS-1). Washington, DC: USDA National Agricultural Statistics Service.

USDA-NASS. (2014). Farm and ranch irrigation survey (2013). 2012 Census of Agriculture, Vol. 3, Special Studies, Part 1 (AC12-SS-1). Washington, DC: USDA National Agricultural Statistics Service.

USDA-NASS. (2018). 2018 Irrigation and water management survey. 2017 Census of Agriculture, Vol. 3, Special Studies, Part 1 (AC-17-SS-1). Issued November 2019. Washington, DC: USDA National Agricultural Statistics Service.

USDC. (1979). 1979 Farm and ranch irrigation survey. 1978 Census of Agriculture, Vol. 5, Special Reports, Part 8 (AC78SR-8). Washington, DC: U.S. Departmet of Commerce, Bureau of the Census.

USDC. (1990). Farm and ranch irrigation survey (1988). 1987 Census of Agriculture, Vol. 3, Related Surveys, Part 1 (AC87RS-1). Washington, DC: U.S. Departmet of Commerce, Bureau of the Census.

Walter, I. A., Allen, R. G., Elliott, R., Jensen, M. E., Itenfisu, D., Mecham, B., \& Martin, D. (2000). ASCE's standardized reference evapotranspiration equation. In Watershed management and operations management 2000. Reston, VA: ASCE. Retrieved from https://doi.org/10.1061/40499(2000)126

Zamora Re, M. I., Rath, S., Dukes, M. D., \& Graham, W. (2020). Water and nitrogen budget dynamics for a maize-peanut rotation in Florida. Trans. ASABE, 63(6), 2003-2020.

https://doi.org/10.13031/trans.13916 